\title{
Assessing the impact of wastewater irrigation on cobalt cadmium and lead contents of
} grains of Sorghum bicolor

\author{
Mohamed Muthana Taher ${ }^{a^{*}}$, Mahfoudh M. S. Al-Hammadi ${ }^{\text {b }}$ \\ ${ }^{a}$ Department of Chemistry, Faculty of Science and Education Aldhalea, Aden University, Aden, Yemen \\ ${ }^{b}$ Department of Chemistry, Faculty of Science, Sana'a University, Sana'a, Yemen
}

\begin{abstract}
The impact of waste irrigation on the concentrations of the metals Cd, Co and Ni contents in grains of Sorghum bicolor was investigated through analyzing (for three seasons 2008-2010s) four different-irrigation sorghum grains samples grown on four different-irrigation soil areas according to the experimental design. Two original soils: Soil, historically and experimentally, irrigated with Wastewater (SHEwastewater), and Soil, historically and experimentally, irrigated with wells water samples were analyzed in the $1^{\text {st }}$ and $2^{\text {nd }}$ seasons. According to the procedures used in the literature, Samples were collected, pretreated, preserved, digested according to the microwave assisted acids digestion procedures, and analyzed for metals by ICP-AES. Quality control was performed and $\% \mathrm{R}(\mathrm{s})$ we have gotten were good for real samples analysis. $\mathrm{Cd}$ and $\mathrm{Pb}$ metal contents of the two types of the original soil samples were not significantly different. In addition, these metal contents of the two types of soil samples have not exceeded the upper EU standards. The average means (of $1^{\text {st }}$ and $2^{\text {nd }}$ seasons) levels of $\mathrm{Cd}$ and $\mathrm{Pb}$ of wastewater were higher than that of wells water. In addition, the average means of these metal ions of both wastewater and wells water was lower than Yemeni standard for irrigation water. Sorghum grains analysis results, for at least two of the three seasons, indicated that: wastewater irrigation resulted in an increase in $\mathrm{Cd}$ and $\mathrm{Pb}$ contents of grains of Sorghum bicolor. Moreover, there is no significant difference between the effect of wastewater and wells water irrigation on Co content of grains of Sorghum bicolor.
\end{abstract}

Keywords: Irrigation; Wastewater; Sorghum Grains; Analysis; wells water.

*Correspondence | Mohamed M. Taher; Department of Chemistry, Faculty of Science and Education Aldhalea, Aden University, Aden, Yemen. Email: mdmuthtaher@gmail.com

Citation | Tahera MM, Al-Hammadi MMS. 2019. Assessing the impact of wastewater irrigation on cobalt cadmium and lead contents of grains of Sorghum bicolor. Arch Pharm Sci ASU 3(1): 90-98

DOI: 10.21608 /aps.2019.20255

Online ISSN: 2356-8380. Print ISSN: 2356-8399.

Received 16 January 2019. Accepted 23 February 2019.

Copyright: ${ }^{\circ} 2019$ Taher and Al-Hammadi, this is an open-access article licensed under a Creative Commons Attribution 4.0 International License (CC BY 4.0), which permits unrestricted use, distribution, and reproduction in any medium, provided the original auth or(s) and source are credited

Published by: Ain Shams University, Faculty of Pharmacy

\section{INTRODUCTION}

In small quantities, certain heavy metals (Chromium, Cobalt, Iron, and Zinc) are a nutritionally essential of a healthy life. Zinc, for example, is a co-factor in over one hundred enzyme reactions. Heavy metals are also common in the manufacture of pesticides, batteries, electroplated metal parts, textile dyes, alloys ... etc; many of these products are in our homes and actually add to our quality of life when properly used [1]. In the other hand, heavy metals e.g., $\mathrm{Cd}$, $\mathrm{Pb}, \mathrm{Ni}$ and others are toxic metals, even for those that have bio-importance, dietary intakes have to be maintained at regulatory limits, as excesses will result in poisoning or toxicity [2]. Toxic effects and exposure sources of heavy metals are summarized in table 1. In our country, like in 
many other countries, some farmers reuse chemically- untreated wastewater to irrigate their crops, some of these crops are of human consumption such as grains of sorghum and wheat. In such countries, the reuse of wastewater in irrigation is still the available solution for problems of wastewater accumulation and scarcity of natural water for irrigation. The scarcity of surface/groundwater for irrigation is an ever increasing problem around the world, owing to which, use of wastewater in agriculture has become a common reality in the third-fourth of the cities in Asia, Africa and Latin America [9]. In the case of soils with poor fertility, it is an important source of nutrients for crop production [10]. In the other hand, wastewater irrigation results in an elevation in some toxic heavy metals in soils. These metals, moved into the soil, concentrate in the food chain, thereby reaching humans and causing chronic or acute diseases [11]. Grains of sorghum bicolor, in our country, is one of the main human consumption crops, these grains are, sometimes, cultivated by some farmers, depending on wastewater irrigation from the second, and occasionally, from the first pond of the treatment plant. Therefore, determination of toxic heavy metals contents of these grains is of great importance since these contents, even at traces, they directly enter within meals into a human body and accumulate in body tissues, and, it might reach toxicity levels causing health risks. There is Yemeni standard for the grain of sorghum [12], Yemeni maximum tolerable limits of toxic heavy metals $(\mathrm{mg} / \mathrm{kg})$ wheat flour [13], and WHO upper limits of daily or weekly intake of trace or micronutrient by the human for each $[14,15]$.

Table 1. Symptoms, toxicity and sources of exposure

\begin{tabular}{cl}
\hline $\mathbf{M}$ & \multicolumn{1}{c}{ Symptoms and toxicity } \\
\hline Cd & $\begin{array}{l}\text { Softening and painful bone fracture; kidney } \\
\text { dysfunction; pneumonitis with pulmonary edema } \\
\text { (may be lethal), lung, kidney and prostate } \\
\text { cancers [3]. }\end{array}$ \\
Co & $\begin{array}{l}\text { Chronic lung problems, breathing problems, skin } \\
\text { irritation or rashes, nausea, vomiting, } \\
\text { cardiomyopathy, nerve, and thyroid problems }\end{array}$ \\
[4].
\end{tabular}

Pb Anaemia, brain damage, anorexia, malaise, appetite loss, diminishing IQ [7], depression of the central nervous system that may result in coma, convulsions and death; immune, reproductive and cardiovascular systems are adversely affected by low exposure; disruption of behaviour [8].

\section{MATERIALS AND METHODS}

\subsection{Chemicals and reagents used}

\section{Sources of exposure}

Volcanoes, weathering, mining, smelting and refining of nonferrous metals, fossil fuel combustion, incineration of cadmium-containing municipal waste, phosphate fertilizers, municipal sewage sludge [3].

Weathering, seawater sprays, volcanoes, sludge use, phosphate fertilizer, burning fossil fuel, industries that use or process cobalt compounds [5].

Sewage sludge and effluent from wastewater treatment plants [6]; lead-added petrol, mining, leadbased paints and pigments, lead solder in food cans, cosmetics, and toys, incinerating lead-containing waste [8].

All chemicals and reagents used were analytical reagent grade and used without previous purification (Table 2). 
Table 2. Chemicals and reagents used

\begin{tabular}{|c|c|c|c|c|c|}
\hline Substance & $\begin{array}{l}\text { Chemical } \\
\text { formula }\end{array}$ & Company & Substance & Chemical formula & Company \\
\hline $\begin{array}{l}\text { Cadmium std. Solution } \\
1000 \mathrm{mg} / \mathrm{L}\end{array}$ & $\mathrm{Cd}\left(\mathrm{NO}_{3}\right)_{2}$ & Scharlau & $\begin{array}{l}30 \% \text { hydrogen peroxide } \\
\text { solution }\end{array}$ & $\mathrm{H}_{2} \mathrm{O}_{2}$ & \\
\hline $\begin{array}{l}\text { Cobalt std. Solution } \\
1000 \mathrm{mg} / \mathrm{L}\end{array}$ & $\mathrm{Co}\left(\mathrm{NO}_{3}\right)_{2}$ & Scharlau & Hydrochloric acid & $\mathrm{HCl}$ & Fluka \\
\hline $\begin{array}{l}\text { Lead std. Solution } 1000 \\
\mathrm{mg} / \mathrm{L}\end{array}$ & $\mathrm{Pb}\left(\mathrm{NO}_{3}\right)_{2}$ & Scharlau & Nitric acid & $\mathrm{HNO}_{3}$ & SIGMA \\
\hline DDW & $\mathrm{H}_{2} \mathrm{O}$ & $\begin{array}{l}\text { Yemen Star } \\
\text { Co. }\end{array}$ & Sulfuric acid & $\mathrm{H}_{2} \mathrm{SO}_{4}$ & BDH AnalaR \\
\hline
\end{tabular}

\subsection{Site description}

Bahira's paddock and Haidrah's paddock were located in Alfallaheen, Ashugiraate farm located south Al-Hawta city in Lahej governorate, Yemen Republic.

\subsection{Experimental design and sampling plan}

In order to evaluate the influence of the wastewater irrigation on the metallic levels in sorghum grains, four sampling areas were designed as follows:

Two sampling areas to be irrigated, experimentally, with wastewater. One of them consisted of a transferred soil, historically, irrigated with wells water for more than 15 years (SHwellsEwastewater), the second consisted of soil, historically irrigated with wastewater for about 15 years, and experimentally irrigated with wastewater (SHEwastewater). These two areas were designed in Bahirah's paddock in Alfallaheen farm south Al-Hawta city in Lahej governorate, Yemen Republic.

Two sampling areas to be irrigated, experimentally, with wells water. One of them consisted of a transferred soil, historically, irrigated with wastewater for about 15 years (SHwastewaterEwells water), and the second consisted of soil, historically, irrigated with wells water for about more than 15 years, and experimentally irrigated with wells water (SHEwells water). These two areas were designed in Haidrah's paddock in Ashugiraate farm south Al-Hawta city in Lahej governorate, Yemen Republic.

Each designed soil area is $12 \mathrm{~m}^{2}$ and $15 \mathrm{~cm}$ in depth, is designed in order to represent about 0.5 ha of its soil area; and it was $2 \mathrm{~m}$ far from surrounding design. Each one of the designed four areas was (for 3sea sons) sowed with sorghum grains and frequently irrigated with the kind of water for which it designed.

Four different-irrigation Sorghum grains samples: G/SHEwastewater (this sample was grown on Soil, historically and experimentally, irrigated with Wastewater, G/SHwells water Wastewater (this sample was grown on Soil historically irrigated with wells water but, experimentally, irrigated with Wastewater), G/SHwastewaterEwells water (this sample was grown on Soil, historically, irrigated with Wastewater but, experimentally irrigated with wells water and G/SHEwells water (this sample was grown on Soil, historically and experimentally, irrigated with Wells water

\subsection{Sample collection, pretreatment, and preservation}


Collection of all samples from location sites were carried out during the period 2008-2010s. The collection stage included the process of packaging and labeling for all samples for the period 2008-2010s. The collected samples were adequate for heavy metals analysis. The containers used for holding the samples were polythene containers, that are suitable according to the literature [16].

\subsubsection{Soil samples}

Two soil samples of the two original soil areas (soil, historically, irrigated with wells water for about more than 15 years and soil, historically, irrigated with wastewater for about more than 15 years) were collected and preserved according to recommended methods described in the literature [17-19]. After 30 days of sowing, a plastic pipe (0.75-inch diameter, 1-foot length) was used as soil sampler. The collected soil samples were spread on a plastic plate beside the sampling area for partial drying then cleaned from stones and plant resides. The soil samples were homogenized, reduced volume, and sealed in clean polythene containers and preserved in a refrigerator at $4-6{ }^{\circ} \mathrm{C}$.

\subsubsection{Water samples}

During the growing period of sorghum, the samples were monthly collected according to the recommended method described in the literature [20]; Wastewater samples were collected from different positions in the second pond of the treatment plant, while wells water samples were collected from the output of the pump. The $\mathrm{pH}$ was measured within 15 min of collection, then acidified to $\mathrm{pH}<2$ then put in sealed, cleaned polythene bottles and preserved in a refrigerator at $4-6{ }^{\circ} \mathrm{C}[21]$.

\subsubsection{Sorghum grains samples}

About 125 days of sowing, four sorghum grains (berries) samples were collected and preserved according to the recommended method described in literature [22]; 10 berries were collected from 10 cores, then put in paper bags and dried in an oven at below $60{ }^{\circ} \mathrm{C}$ for about 20 $\mathrm{h}$, then the grains were taken from the berries and put in cleaned and sealed polythene containers.

\subsection{Instruments and equipment}

Smart pH meter SM101M Milwaukee Hanna. A calibrated digital analytical balance, MEETER AE 100, Switzerland (sensitivity $0.0001 \mathrm{~g}$ to 100.0 g). Vista MPX CCP Simultaneous ICPAES Instrument, Varian. Drying oven with thermostatic control. Microwave digester, Milestone, Microwave Laboratory System, Ethos Touch Control, N. America. Polyethylene containers of different capacities for water, soil, and grains of sorghum bicolor samples. Ceramic mortar and pestle. Polypropylene sieves $(1 \mathrm{~mm}$, $0.5 \mathrm{~mm})$.

\subsection{Samples preparation and analysis}

Sample preparation has to fulfill at least one of the following: making the test sample physically or chemically measurable by the analytical technique; elimination of the interferences; improving the relationship between the amount of analyte and matrix [23]. The dry ash digestion method is not suitable for heavy metals determination. With the exception of $\mathrm{Zn}$, recoveries using dry ash destruction if compared to the microwave method, consistently was too low [24]; the method involving $\mathrm{HNO}_{3}$ acid/ $\mathrm{H}_{2} \mathrm{O}_{2}$ is by far the easiest and fast, at the same time it is reproducible and allows to obtain recoveries comparable with laborious approach [25]; losses of Lead and Nickel occur, in open wet digestion, when nitric and hydrochloric acid is used respectively [26]. The microwave-assisted digestion procedure leads to accurate results of analysis and could be recommended as a standard approach for plant material samples [27]. 
Ultrasonic assisted acid digestion and a traditional hot plate acid digestion was used for digestion of different samples such as plant samples and the analytical results for heavy metals showed no significant difference at $95 \%$ confidence limit $(\mathrm{P}<0.05)$ [28]. "For samples with high organic matter content, such as organic horizons of forest floor layers, plant material, and organic soils, nitric acid digestion could substitute microwave hydrofluoric acid digestion [29].

Microwave-assisted acids digestion procedures were used in this present study for digestion of water, soil, and sorghum grains samples.

\subsubsection{Soil samples}

Each of the preserved soil samples was homogenized and about $10 \mathrm{~g}$ was dried to a constant weight in an oven at below $60{ }^{\circ} \mathrm{C}$, and then it was ground to fine powder. From this powder, $0.25 \mathrm{~g}$, adjusted to four decimals, was digested with conc. acids $\left(9 \mathrm{~mL} \mathrm{HNO}_{3}\right.$ and $3 \mathrm{~mL}$ $\mathrm{HCl}$ ) in the microwave under pressure programmed for soil sample digestion. The extract solution was diluted to $25 \mathrm{~mL}$ with DDW, transferred into polythene bottles and 1-2 h of extraction, the extract solutions were analyzed.

\subsubsection{Water samples}

From each of the preserved water samples, 45 $\mathrm{mL}$ was digested by Conc. Acids $\left(4 \mathrm{~mL} \mathrm{HNO}_{3}+\right.$ $1 \mathrm{~mL} \mathrm{HCl}$ ) with microwave under pressure programmed for water sample digestion. The extract solution was diluted to $50 \mathrm{~mL}$ with DDW and transferred into polythene bottles then, 1-2hrs of extraction, the extract solutions were analyzed.

\subsubsection{Sorghum grains samples}

About $5 \mathrm{~g}$ of each preserved sample was dried to constant weight in an oven at below $60{ }^{\circ} \mathrm{C}$, ground to fine powder, homogenized and then 0.5 $\mathrm{g}$, adjusted to four decimals was digested by a mixture $\left(9 \mathrm{~mL}\right.$ conc. $\mathrm{HNO}_{3}$ and $3 \mathrm{~mL} 30 \%$ $\mathrm{H}_{2} \mathrm{O}_{2}$ ) with microwave under pressure and program (5.5 min to reach $180 \pm 5.0{ }^{\circ} \mathrm{C}$ and continuing at this temperature for $9.5 \mathrm{~min}$ ). The extract solution was diluted to $25 \mathrm{~mL}$ with DDW and transferred into polythene bottles then; 1-2 $\mathrm{h}$ of extraction, the extract solutions were analyzed. Quality control, recovery percent (\%R) was performed.

\section{RESULTS AND DISCUSSION}

\subsection{Soil analysis results}

The $\%$ recovery $(\% \mathrm{R})$ and analysis results of soil samples are shown in table 3 The $\% \mathrm{R}(\mathrm{s})$ were 111 and $108 \%$ for $\mathrm{Cd}$ and $\mathrm{Pb}$ respectively. From table 3 and Fig. 1, it is clear that $\mathrm{Cd}$ and $\mathrm{Pb}$ contents of the two original soil samples were not significantly different, $0.7187 / 0.6602$ for $\mathrm{Cd}$ and 10.47/8.236 for $\mathrm{Pb}$.

Table 3. Quality control and analysis results of soil samples, $1^{\text {st }}$ season (winter 2008-2009) and EU standard, 2001.

\begin{tabular}{|c|c|c|c|c|c|c|c|c|}
\hline \multirow[b]{3}{*}{ Metal } & \multicolumn{3}{|c|}{ Q.C Spike $39.95 \mu \mathrm{g} \mathrm{g}^{-1}$} & \multicolumn{4}{|c|}{ Results of different soil samples } & \multirow{3}{*}{$\begin{array}{c}\text { EU standard } \\
(20)\end{array}$} \\
\hline & \multirow{2}{*}{$\begin{array}{l}\text { Un spiked matrix } \\
\qquad\left(\mu \mathrm{g} \mathrm{g}^{-1}\right)\end{array}$} & \multirow{2}{*}{$\begin{array}{c}\text { Spiked matrix } \\
\qquad\left(\mu \mathrm{g} \mathrm{g}^{-1}\right)\end{array}$} & \multirow{2}{*}{$\% \mathbf{R}$} & \multicolumn{2}{|c|}{ SHEwastewater } & \multicolumn{2}{|c|}{ SHEwells water } & \\
\hline & & & & $\begin{array}{c}\text { Average } \\
\left(\mu \mathrm{g} \mathrm{g}^{-1}\right) \mathbf{n}=3\end{array}$ & RSD & $\begin{array}{c}\text { Average } \\
\left(\mu \mathrm{g} \mathrm{g}^{-1}\right) \mathrm{n}=3\end{array}$ & RSD & \\
\hline $\mathrm{Cd}$ & 0.5616 & 44.79 & 111 & 0.7187 & 4.1 & 0.6602 & 3.8 & $1-3.0$ \\
\hline $\mathrm{Pb}$ & 8.305 & 51.56 & 108 & 10.47 & 27.4 & 8.236 & 21.6 & $50-300$ \\
\hline
\end{tabular}




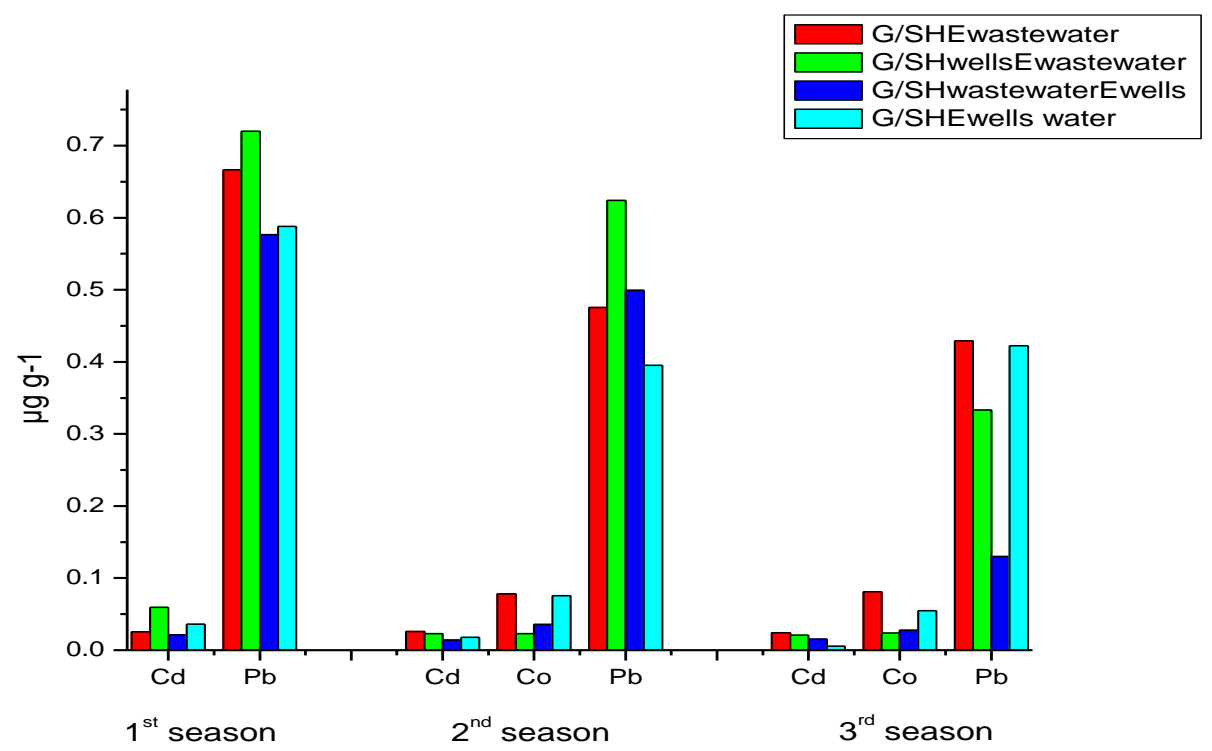

Fig. 3. Metals ions $\mu \mathrm{g} \mathrm{g}^{-1}$ of different-irrigation grains of sorghum bicolor $1^{\text {st }}, 2^{\text {nd }}$ and $3^{\text {rd }}$ season.

\subsection{Water analysis results}

Quality control as laboratory reagent blank (LRB) and sample matrix spike (SMS) was performed. The $\% \mathrm{R}$ and analysis results of water samples are shown in table 4 . The $\% \mathrm{R}$ for $1^{\text {st }}$ season was from 90 to $114 \%$ for wells water and wastewater for $\mathrm{Cd}$ and $\mathrm{Pb}$.

From table 4, it is very clear that the average levels (mg/L) mean (of $1^{\text {st }}$ and $2^{\text {nd }}$ seasons for $\mathrm{Cd}$ and $\mathrm{Pb} .2^{\text {st }}$ season for $\mathrm{Co}$ ) of $\mathrm{Cd}, \mathrm{Co}$, and $\mathrm{Pb}$ of wastewater were higher than that of wells water, $0.00745 / 0.00405, \quad 0.00315 / 0.00189$ and $0.0247 / 0.0136$ respectively; (t-test, $\mathrm{p}=0.000$ $0.02)$. In addition, the average means of all metal ions of both wastewater and wells water was lower than Yemeni standard for irrigation water.

\subsection{Sorghum grains analysis results}

\subsubsection{Quality control}

The obtained data was summarized in table 5. This Table shows that the $\% \mathrm{R}(\mathrm{s})$ in the $1^{\text {st }}$ season were 99 and $91 \%$ for $\mathrm{Cd}$ and $\mathrm{Pb}$. In the $2^{\text {nd }}$ season, the \% R(s) were from 107 to 110 for all metal ions. In the $3^{\text {rd }}$ season, the $\% \mathrm{R}$ was from 92 to 121 for all metal ions.

\subsubsection{Metal ions levels of different-irrigation grains of Sorghum bicolor}

It is clear, as shown in table 6 and Fig. 1, that, in the $1^{\text {st }}$ season, $\mathrm{Cd}$ level in G/SHwellsEwastewater was higher than that in G/SHEwells $0.05954 / 0.03606$ ( $p=0.08$ ), in the other hand, its level in G/wastewater Ewells was lower than that in G/SHEwastewater $0.02141 / 0.02528(\mathrm{p}=0.24)$, this indicated that, experimentally, wastewater irrigation raised $\mathrm{Cd}$ level in sorghum grains whereas wells irrigation did not significantly affect. In the $2^{\text {nd }}$ season, $\mathrm{Cd}$ level was higher 0.02313/0.01794 $(\mathrm{p}=0.02)$ due to experimentally wastewater irrigation and was lower $0.01382 / 0.02570(\mathrm{p}=0.008)$ due to wells irrigation. In the $3^{\text {rd }}$ season, Cd level was also higher $0.02097 / 0.005445(\mathrm{p}=0.01)$ due to wastewater, and lower 0.01510/0.02438 $(\mathrm{p}=0.08)$ due to wells irrigation.

Co level in sorghum grains in the $2^{\text {nd }}$ season was lower due to both, experimentally, 
wastewater $0.02302 / 0.07568(\mathrm{p}=0.005)$ and wells $0.03573 / 0.07807(\mathrm{p}=0.03)$ irrigation. In the $3^{\text {rd }}$ season, Co level was lower due to, experimentally, both, wastewater $0.02374 / 0.05469 \quad(p=0.14)$ and wells $0.03573 / 0.08118(\mathrm{p}=0.11)$ irrigation.

$\mathrm{Pb}$ level, in the $1^{\text {st }}$ season, of $\mathrm{G} / \mathrm{SH}$ wellsEwastewater was higher than that in G/SHEwells $0.7201 / 0.5881 \quad(p=0.03)$, in the other hand, its level of G/SHwastewaterEwells was lower than that in $\mathrm{G} /$ wastewater $0.5767 / 0.6666(\mathrm{p}=0.03)$, this indicated that, experimentally, wastewater irrigation raised $\mathrm{Pb}$ level in sorghum grains whereas wells irrigation lowered it. In the $2^{\text {nd }}$ season, $\mathrm{Pb}$ level was higher $0.6242 / 0.3954 \quad(\mathrm{p}=0.03)$ due to wastewater irrigation and did not significantly affect by wells irrigation 0.4991/0.4756. In the $3^{\text {rd }}$ season, $\mathrm{Pb}$ level was lower due to experimentally, both wastewater $0.3332 / 0.4223(\mathrm{p}=0.08)$ and wells $0.1300 / 0.4290(\mathrm{p}=0.01)$ irrigation.

In addition, from Table 3.4, it is clear that, in the $1^{\text {st }}, 2^{\text {nd, }}$ and $3^{\text {rd }}$ seasons. $\mathrm{Cd}$ and $\mathrm{Pb}$ levels in all grains have not exceeded Yemeni maximum tolerable limit.

Table 4. Quality control and metal ions levels (mg/L) of wastewater and wells water (mean of $1^{\text {st }}$ and $2^{\text {nd }}$ season), and Yemeni standard for irrigation water $\mathrm{mg} / \mathrm{L}$ (Ye. std.).

\begin{tabular}{|c|c|c|c|c|c|c|c|c|c|c|c|}
\hline \multirow[b]{2}{*}{$\begin{array}{l}\text { Sample } \\
\text { M } \\
\end{array}$} & \multicolumn{3}{|c|}{$\begin{array}{c}\text { Wastewater Q.C } \\
\text { Spike 0.05 }(\mathrm{mg} / \mathrm{L})\end{array}$} & \multicolumn{3}{|c|}{$\begin{array}{c}\text { Wells water Q.C } \\
\text { Spike } 0.05(\mathrm{mg} / \mathrm{L})\end{array}$} & \multicolumn{4}{|c|}{$\begin{array}{l}\text { Metal ions concentration }(\mathrm{mg} / \mathrm{L}) \\
\text { mean of water samples }\end{array}$} & \multirow{2}{*}{$\begin{array}{c}\text { Ye. } \\
\text { std. } \\
(\mathrm{mg} / \mathrm{L}) \\
{[30]}\end{array}$} \\
\hline & $\begin{array}{c}\text { Un } \\
\text { spiked } \\
\text { matrix } \\
(\mathrm{mg} / \mathrm{L})\end{array}$ & $\begin{array}{l}\text { Spiked } \\
\text { matrix } \\
(\mathrm{mg} / \mathrm{L})\end{array}$ & $\% \mathrm{R}$ & $\begin{array}{c}\text { Un } \\
\text { spiked } \\
\text { matrix } \\
(\mathrm{mg} / \mathrm{L})\end{array}$ & $\begin{array}{l}\text { Spiked } \\
\text { matrix } \\
(\mathrm{mg} / \mathrm{L})\end{array}$ & $\% \mathrm{R}$ & Mean & RSD & Mean & RSD & \\
\hline $\mathrm{Cd}$ & 0.0103 & 0.0572 & 93.8 & 0.0102 & 0.0584 & 96.4 & 0.00745 & 1.3 & 0.00405 & 1.2 & 0.01 \\
\hline $\mathrm{Co}$ & NA & NA & NA & NA & NA & NA & 0.00315 & 8 & 0.00189 & 6.7 & 0.05 \\
\hline $\mathrm{Pb}$ & 0.0212 & 0.0663 & 90.2 & 0.0140 & 0.0709 & 114 & 0.0247 & 3.7 & 0.0136 & 1.5 & 5.0 \\
\hline $\mathrm{pH}$ & 7.96 & 7.96 & - & 7.30 & 7.30 & - & 7.96 & - & 7.30 & - & $6.5-8.4$ \\
\hline
\end{tabular}

Table 5. Quality control for Sorghum grain analysis $1^{\text {st }}, 2^{\text {nd }}$ and $3^{\text {rd }}$ seasons.

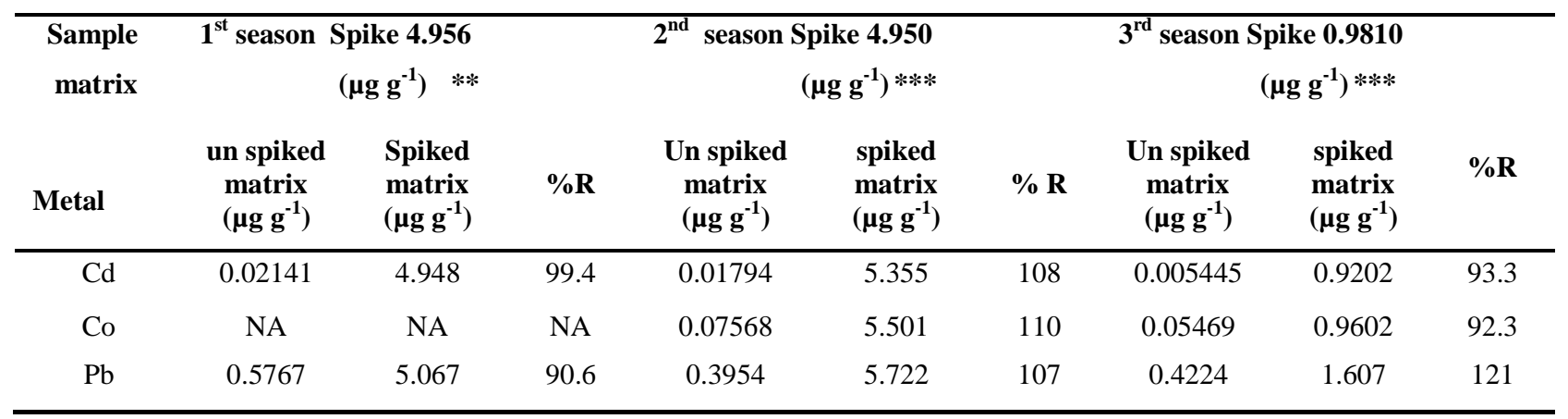

NA= Not Applicable.

$* *=\mathrm{G} / \mathrm{SH}$ wastewaterEwells water

$* * *=\mathrm{G} /$ SHEwells water 
Table 6. Metal ions levels $\left(\mu \mathrm{g} \mathrm{g}^{-1}\right)$ of different-irrigation grains of sorghum bicolor $1^{\text {st }}, 2^{\text {nd }}$ and $3^{\text {rd }}$ seasons, (Ye. Max. $\mathrm{mg} / \mathrm{kg}$ wheat flour) and (WHO mg/day.adult).

\begin{tabular}{|c|c|c|c|c|c|c|c|c|c|c|c|c|c|c|}
\hline \multirow{2}{*}{$\begin{array}{l}\text { Grains } \\
\text { Metal }\end{array}$} & \multicolumn{3}{|c|}{ G/SHEwastewater } & \multicolumn{3}{|c|}{ G/SHwells waterE wastewate } & \multicolumn{3}{|c|}{ G/SHwastewaterEwells water } & \multicolumn{3}{|c|}{ G/SHEwells water } & \multirow{2}{*}{$\begin{array}{c}\text { Ye. } \\
\text { max. } \\
{[13]}\end{array}$} & \multirow{2}{*}{$\begin{array}{c}\text { WHO } \\
\text { ULs/d.ad } \\
{[14-15]}\end{array}$} \\
\hline & $\begin{array}{c}1^{\text {st }} \\
\text { Season }\end{array}$ & $\begin{array}{c}2^{\text {nd }} \\
\text { season }\end{array}$ & $\begin{array}{c}3^{\text {rd }} \\
\text { season }\end{array}$ & $\begin{array}{c}1^{\text {st }} \\
\text { Season }\end{array}$ & $\begin{array}{c}2^{\text {nd }} \\
\text { season }\end{array}$ & $\begin{array}{c}3^{\text {rd }} \\
\text { season }\end{array}$ & $\begin{array}{c}1^{\text {st }} \\
\text { Season }\end{array}$ & $\begin{array}{c}2^{\text {nd }} \\
\text { season }\end{array}$ & $\begin{array}{c}3^{\text {rd }} \\
\text { season }\end{array}$ & $\begin{array}{c}1^{\text {st }} \\
\text { Season }\end{array}$ & $\begin{array}{c}2^{\text {nd }} \\
\text { season }\end{array}$ & $\begin{array}{c}3^{\text {rd }} \\
\text { season }\end{array}$ & & \\
\hline $\mathrm{Cd}$ & 0.02528 & 0.02570 & 0.02438 & 0.05954 & 0.02313 & 0.02097 & 0.02141 & 0.01382 & 0.01510 & 0.03606 & 0.01794 & 0.005445 & 0.10 & $\begin{array}{c}0.065- \\
0.055\end{array}$ \\
\hline Co & - & 0.07807 & 0.08118 & - & 0.02302 & 0.02374 & - & 0.03573 & 0.02766 & - & 0.07568 & 0.05469 & - & - \\
\hline $\mathrm{Pb}$ & 0.6666 & 0.4756 & 0.4290 & 0.7201 & 0.6242 & 0.3332 & 0.5767 & 0.4991 & 0.1300 & 0.5881 & 0.3954 & 0.4223 & 2.00 & $\begin{array}{l}0.2- \\
0.23\end{array}$ \\
\hline
\end{tabular}

\section{CONCLUSION}

Experimentally, wastewater (from Al-Hawtah Lahej treatment plant) irrigation results in an increase in cadmium and lead.

Experimentally, there is no significant difference between the effect of wastewater and wells water irrigation on the cobalt content of sorghum grains. Wastewater (as Al-Hawtah Lahej treatment plant) irrigation must not be used for the production of grains of sorghum (as human food) since it raised cadmium and lead levels in grains of Sorghum bicolor.

Al-Hawtah Lahej treatment plant must be maintained and keep management to reduce heavy metals pollution by metal sedimentation.

\section{Conflict of interest}

The authors declare no conflict of interests.

\section{REFERENCES}

1. D. O. Carpenter, IJOMEH14, 3 (2001) 209218

2. J. O. Duruibe, M. O. Ogwuegbu, J. N. Egwurugwu; Int. J. Physic. Sci., 2, 5(2007) 112-118.
3. World Health Organization (WHO), exposure to Cadmium: A major public health concern (2010).

4. http://www.testcountry.org/most-commonsigns-symtoms-of-cobalt, 11th April 2013.

5. http://www.acu-cell.com/index, 2nd September 2011.

6. A. Behbahaninia, S. A. Mirbagheri, J. Nouri; Iran. J. Environ. Health. Sci. Eng.7, 5 (2010) 401-406

7. U. Farooq, J. A. Kozinski, M. A. Khan, M. Athar; Bioresource Techno. 101 (2010) 5043-5053.

8. WHO, Library Cataloguing-in-Publication Data, (2010) 18-34

9. M. N. Jagtap, M. V. Kulkarni, P. R. Puranik; American-Eurasian J. Agric. \& Environ. Sci., 8, 5 (2010) 487-493

10. Ahmed, T. A., Al-Hajri, H. H; Int. J. Environ. Res., 3, 4 (2009) 503

11. M. W. Kadi, J. Haz. Mater, 168 (2009) $1280-1283$

12. Yemen Standard 1218/2005 for grains of Sorghum bicolor

13. Yemen Standards 151/2005 for wheat flour. 
14. WHO, Trace elements in human nutrition and health, Geneva (1996).

15. FAO/WHO, Guidelines on food fortification with micronutrients, WHO Library Cataloguing-in-Publication Data (2006)

16. R. Saxena, A. K. Sing; Analytica Chimica Acta 340 (1997) 285

17. M. Harvey, R. M. Baker; Thomas Graham House (2002) 22

18. M. J. Mohammad, N. Mazahreh; 34, 9 \& 10,(2003)1281-1294

19. M. McGrath, Johnstown Castle Research Center, Oxford (2000) 1-16

20. H. Langenkamp, L. Marmo; (2001)

21. Leo M. L. Nollet, CRC Press (2007) 278280

22. P. Sosinski, J. Bilyeu, C. E. Caporale; Procedures for OASQA, Revision 12.0, (2009) 8

23. K. Danzer, Springer-Verlag (2007) 23

24. F. M. Tack, N. Bogaert, M. G. Verloo, F. Hendrickx, J. P. Maelfait, J. Mertens; Int. J. Environ. Anal. Chem. 78, 2 (2000) 149-158.

25. C. Yafa, J. G. Farmer; Analytica Chimica Acta 557 (2006) 296-303

26. G. Somer, A. N. Ünlü; Turk J Chem, 30 (2006), $745-753$.

27. H. P. Motrenko, B. Danko, R. Dybczyṅski, A. Ammerlaan, P. Bode;

Analytica Chimica Acta 408 (2000) 89

28. Kazi TG, Jamali MK, Arain MB, Afridi HI, Jalbani N, Sarfraz RA, Ansari R; J. Haza. Mater. 161, 2-3 (2009)1391

29. J. Sastre, A. Sahuquillo, M. Vidal, G. Analytica Chimica Acta 462 (2002) 59

30. Yemen Standard 150/2001 for Irrigation waters. 